\title{
Implementation of STEM-Based Learning for Strengthening Science Literacy of Students
}

\author{
Ferdinandus Bele Sole ${ }^{1^{*}}$ \\ ${ }^{1}$ Basic Education Study Program, Universitas Negeri Yogyakarta
}

DOI: $10.29303 /$ ippipa.v7iSpecialIssue.1266

\section{Article Info}

Received: November 20th 2021

Revised: December 25th 2021

Accepted: December 31th, 2021

\begin{abstract}
This study aims to analyze the STEM approach in learning to strengthen the scientific literacy of students. The method used in this research is qualitative research with data collection techniques, namely literature studies. The data collection method is by reading, identifying, and analyzing, then categorizing, classifying, and describing. In this research, the study of relevant journals, articles, are used to find out how to increase students' science literacy by using STEM in elementary schools. Based on the results of research, the literature study states that the use of STEM-based learning effectively improves the student's science literacy. The results of the research analysis showed that the results of the pretest scores of students had low concept understanding in the experimental class and the control class. After being given treatment, the results of the posttest scores showed a significant increase in the experimental class.
\end{abstract}

Keywords: Implementation; STEM-Based Learning; Science Literacy

Citation: $\quad$ Sole, F. B. (2021). Implementation of STEM-Based Learning for Strengthening Science Literacy of Students. Jurnal Penelitian Pendidikan IPA, 7(SpecialIssue), 382-388. https://doi.org/10.29303/jppipa.v7iSpecialIssue.1266

\section{Introduction}

Law Number 20 of 2003 concerning the National Education System Article 4 paragraph 5 states that education is carried out by developing a culture of reading, writing, and arithmetic for all members of the community (Depdiknas, 2003). This article discusses the principles in organizing an educational institution that cultivates reading, writing, and arithmetic (calistung) activities. The existence of this principle becomes the basis and guideline for education providers to design learning activities that are oriented towards literacy and numeracy.

The importance of literacy and numeracy became one of the topics of discussion at the World Economic Forum in 2015 which discussed the New Vision in Education. This forum sets out 16 skills needed by students in the 21st century both at the primary and secondary education levels. These skills are divided into 3 categories, namely basic literacy, competence, and character quality.
The basic literacy category represents how students apply key skills in everyday tasks. These skills serve as the basis so that students can master skills at the next level, namely competence and character quality so that mastery of basic literacy becomes a mandatory and important thing for students to have. The basic literacy components referred to in the World Economic Forum are literacy, namely literacy, numeracy, scientific literacy, digital literacy, financial literacy, and cultural and civic literacy.

Literacy and literacy are the most basic literacy that must be possessed by all students at the elementary school level. This is because the ability of students in these two literacy components is the basis and foundation for literacy mastery in the other 4 components, so it is necessary to get more attention from all groups, both teachers, parents, community, non-governmental organizations (NGOs) and other stakeholders.

Mastery of the six basic literacy that have been established by the World Economic Forum in 2015 is very important not only for students but also for

\footnotetext{
*Email: ferdinandusbele.2021@student.uny.ac.id
} 
schools, parents, and all members of the community. To build a literacy culture in all areas of education (family, school, and community), since 2016 the Ministry of Education and Culture has initiated the National Literacy Movement (GLN) as part of the implementation of the Minister of Education and Culture Regulation Number 23 of 2015 concerning the Growth of Character.

The National Literacy Movement is an effort to strengthen the synergy between the main units of the literacy movement by gathering all potentials and expanding public involvement in developing and cultivating literacy in Indonesia. This movement will be carried out comprehensively and simultaneously, starting from the family realm to schools and communities throughout Indonesia. In its implementation, GLN is divided into 3 spheres, namely the Literacy Movement in Schools (GLS), the Family Literacy Movement (GLK), and the Community Literacy Movement (GLM).

One of the scopes in GLN is the School Literacy Movement. GLS is a comprehensive effort that involves all school members (teachers, students, parents) and the community, as part of the education ecosystem. The indicators of the implementation of the GLS are divided into 3 areas, namely class-based, school culture, and also community-based. On a class basis, there are 3 indicators, namely 1). A number of literacy facilitator training, 2) Intensity of utilization and application of literacy in learning, 3) Reading literacy scores in PISA, TIMSS, PIRLS, and INAP.

The second indicator, it can be done by integrating learning approaches that can improve students' literacy skills. One of the learning approaches that can be used to support the implementation of students' scientific literacy in the classroom is STEMbased learning (Science, Technology, Engineering, and Mathematics).

The scientific literacy ability of each individual needs to be improved, especially for elementary school students. One alternative to improve scientific literacy skills in elementary school students is to apply a learning approach that can motivate students to be interested in participating in the learning process. The right approach is applied in improving scientific literacy skills, namely the STEM approach that students

By using the STEM approach the learning process will be more varied and innovative so can learn various academic concepts that are juxtaposed with the real world. STEM learning can help students gain complete knowledge, be more skilled in dealing with real-life problems and develop students' critical thinking. STEM is an effective approach in implementing Integrative thematic learning because it combines four main areas of education, namely science, technology, engineering, and mathematics.

The STEM learning model that integrates several lessons can enrich the repertoire of students' knowledge. Students can feel the benefits and apply the theory they learn directly. In terms of literacy, through STEM students receive various information which can then create ideas and creativity. Students are also trained to read and write. In terms of numeracy, students are always used to doing calculations and analyzing data in the form of numbers or graphs.

Based on this background, the researcher intends to analyze the STEM approach in learning to strengthen the scientific literacy of elementary school students. State the objectives of the work and provide an adequate background, avoiding a detailed literature survey or a summary of the results.

\section{Method}

This research is a qualitative type with a literature study approach. The literature study is the study of data from various reference books and the results of previous research that are relevant to the research in order to obtain a theoretical basis for the problem to be examined (Sarwono, 2006). The data collection method is by reading, identifying, and analyzing, then categorizing, classifying, and describing. In this research, the study of relevant journals, articles, is used to find out how to increase students' science literacy by using STEM in elementary schools.

\section{Result and Discussion}

STEM education is able to form human resources' (HR) reasoning and thinking critically, logically, and systematically (Asmuniv, 2015). Learning through the integration of STEM can make students better prepared in the STEM field jobs (Brown, et al., 2011), increase interest and achievement in mathematics and science (Stohlmann, et al., 2012). OECD (2013) stated that an understanding of science and technology significantly contributes to the personal, social, professional and cultural lives of everyone. National STEM Education Center (2014) in Firman, (2015) stated that STEM learning does not only mean strengthening of practical education of STEM fields separately, but it is rather to develop an educational approach that integrates science, technology, engineering and math, by focusing on the educational process in daily life real solving. Through STEM, learning process will be more meaningful so students' scientific literacy can be achieved. 
Lu \& Lin, (2018) says that STEM education can be chosen to foster the innovative spirit and practical capacity of the students by integrating the knowledge and spirit of each subject and applying them to real life. One way to address the need for practical action in STEM Education is through the introduction of STEM Project-Based Learning. STEM Project-Based Learning is a learning model based on the STEM approach to education and integrated with the project-based curriculum design (Tseng, 2013). Based on the research by Lou, (2017), there will five stages of STEM ProjectBased Learning, which are the preparation stage, implementation stage, presentation stage, evaluation stage, and the last is the correction stage that teacher can adopt in the learning activity. Infusing design principles enhances applicability in the real world and helps prepare students to relate their knowledge in tackling the problem, with an emphasis on connecting with what STEM professionals are actually doing in their jobs (Capraro, 2013).

This analysis is used to measure the improvement in science literacy by using STEM. Based on the analysis of the results of the research conducted by (Khaeroningtyas, et. al., 2016), the research was conducted in SMP Negeri 1 Bumiayu with a population of seventh-grade students in odd semester academic year 2015/2016. Samples are two classes of class VII E (experimental group) and class VII G (control group). Sample selection was done by the random sampling class technique. The improvement of students' scientific can be seen through the Gain value data formulated from score minus. The data is presented in Figure 1.

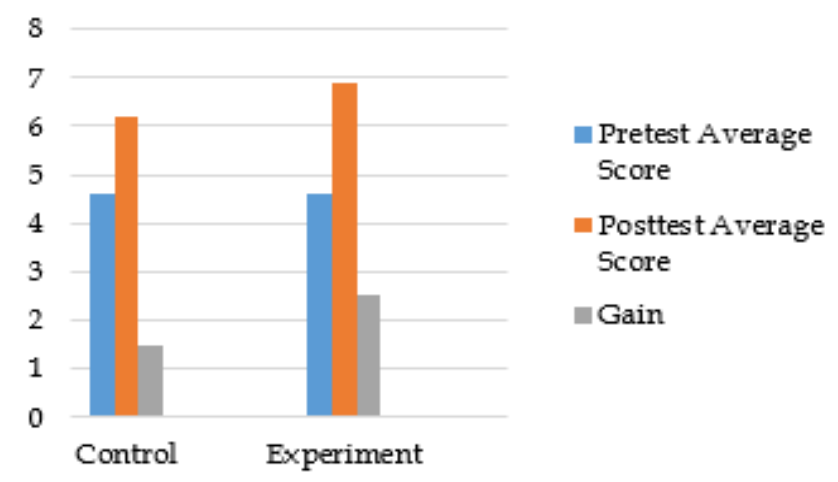

Figure 1. Pretest and Posttest Scores of Students in Temperature Material

Independent Samples Test The test results showed the value of Sig. (2-tailed) $=0.003<\alpha=0.05$. Therefore, it can be interpreted that the null hypothesis is rejected, which means there is a significant difference in students' scientific literacy improvement in the control and the experimental group. The average score of students' scientific literacy in experimental and control groups is presented in Table 1.
Table 1. N- Gain Average and Classification of Students' scientific literacy

\begin{tabular}{lll}
\hline Group & N-Gain Average & Classification \\
\hline Control & 0.27 & Low \\
Experiment & 0.44 & Moderate \\
\hline
\end{tabular}

The improvement of students' scientific literacy who obtained STEM learning using the $6 \mathrm{E}$ Learning by Design TM Model in temperatures material was higher than non-STEM learning. Scientific literacy is in line with STEM literacy, for example understanding the concepts and procedural skills and ability of the individual to demonstrate STEM relation to the personal, social, and global issues (Bybee, 2010). Students who obtained STEM learning will be more literate in STEM aspects, so students' scientific literacy will automatically increase. This improvement also shows that the junior high school students can receive STEM learning, as well as Verma, et al., (2011) that has successfully engaged students in STEM learning through the 5E Learning Cycle.

The improvement of students' scientific literacy can happen because they are more motivated to be able to design a thermometer scale and given the chance to access information via the internet (technology). Gutherie, et al., (2000) in their research concluded that integrating STEM learning can increase students' motivation in learning.

Stohlmann, et al., (2012) stated that there are some advantages in STEM learning, including making students be better at solving problems, innovators, inventors, confident, thinking logically and literate in technology; it also can improve students' creative thinking skills (Oktavia, 2015). The research conclusion is STEM learning using 6E Learning by Design TM Model in temperature and its changes can improve students' scientific literacy. The result indicates that scientific literacy can be improved if this model is applied continuously.

Another study was conducted by Kartini, et al., (2021). The method used was a pre-experimental method with one group pretest-posttest design, without the control group (Fraenkel, 2011). Both methods and designs involved one group that is a pretest, exposed to a treatment, then post-tested. This method was suitable for the purpose of this study, which was to investigate the effect of STEM ProjectBased Learning on students' STEM Literacy in learning the earth layer and disaster. Table 2. shows how the research design used in this study.

Tabel 2. One group pretest-posttest design

\begin{tabular}{lll}
\hline $\mathrm{O}$ & $\mathrm{X}$ & $\mathrm{O}$ \\
\hline Pre test & $\begin{array}{l}\text { STEM-Project Based } \\
\text { Learning }\end{array}$ & Post test \\
& \\
\hline
\end{tabular}


The population in this research was all students in 7th grade at one of the Junior High schools in Bandung. The sampling technique used in this research was convenience sampling. The researcher selects participants because they were available to be studied. There were 30 students in one class at this school with 13 male students and 17 female students with an age average of $12-13$ years old.

The multiple-choice question was given to the students as a tool to see the students' STEM literacy before and after the teaching-learning process. The multiple-choice question is developed based on the study by Zollman, (2012) and has been given to the students in the class. To obtain the result of the test, it was analyzed by SPSS and also analyzed by using the normalized gain test based on Hake's rule of normalization. The average $\mathrm{N}$-gain score of students' curiosities is in pretest and posttest shown in Table 3.

Table 3. Students' STEM literacy score for pretest and posttest

\begin{tabular}{llll}
\hline Group & Average & N-Gain & Classification \\
\hline Pretest & 34.70 & \multirow{2}{*}{0.47} & Medium \\
Posttest & 68.10 & & \\
\hline
\end{tabular}

The result of student learning activity shown in Table 3 . that the mean score obtained by students before the implementation of STEM Project-Based Learning increased from the pretest, which is 34.70 , while the mean score after the implementation of posttest is 68.10. A normalized gain shows the improvement in each aspect of students' STEM Literacy by the implementation of STEM Project-Based learning experienced by the participants is 0.47 . Based on Hake's rules of normalization, this score $\mathrm{N}$-gain is categorized as medium. To see the detail of the students' STEM Literacy, then the data is also analyzed in each aspect for pretest and posttest. The result of students' STEM Literacy in detail is presented in Figure 2.

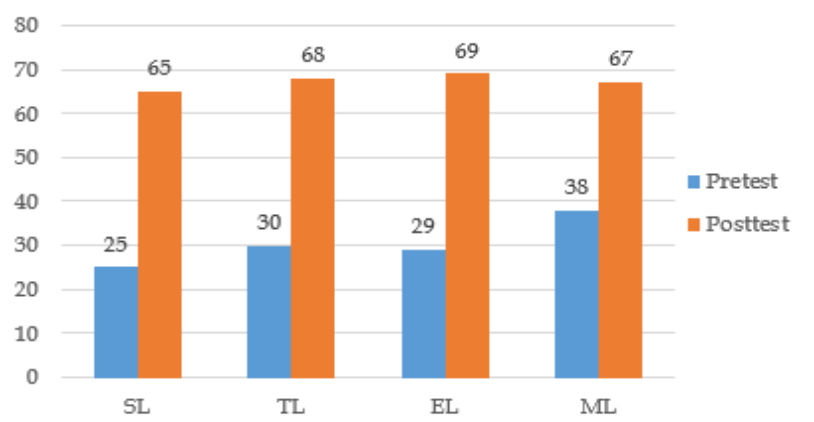

Figure 2. Result of mean score in each aspect of student STEM literacy

Based on Figure 2. the mean score of all aspects of STEM Literacy increased. On student science literacy, the increasing mean score from 25 in pretest to 65 on the posttest, from student technology literacy, the prior mean score shows 30, and the posttest mean scores show 69. While on student engineering literacy, the pretest means the score is 29.3 , and the posttest is 68.6. For the student's mathematical literacy, the mean score increases from 37.5 on the pretest to 66.0 on the post-test. It means there is an improvement for students' STEM Literacy after implementing STEM Project-Based Learning since the number of students for each aspect of STEM Literacy. This result is in line with the research by Persaud-Sharma, (2012) that previously investigated the relationship between case study and STEM literacy. The whole profile of students' STEM Literacy needs to be processed by analyzing the improvement of each STEM literacy aspect.

The conclusion in this research is from the scoring results of the objective test consisting of multiple-choice questions, the implementation of STEM Project-Based Learning as a learning model in the Earth Layer and disaster topic could improve the students' STEM Literacy. It can be proved by the results of NGain is 0.47 , which means categorized as medium. The result showed that STEM Project-Based learning in Earth Layer and disaster topic could be an alternative learning tool to enhance students' STEM Literacy in this pandemic time.

Another research was conducted by Sulistiyowati, et al, (2018). The research used mixedmethod with exploratory sequential design in the Nonequivalent Control Group Design. Samples were taken using the purposive sampling technique. This study involved 25 eighth grade students of class $\mathrm{F}$ as the experimental class and 25 eighth grade students of class A as the control class in SMP Negeri 2. Pugung. The data collecting techniques were observation method, questionnaire, and test. The data were analyzed using an independent sample t-test to see the effectiveness of the learning in both groups.

The results of data analysis showed that STEMbased worksheets influenced student learning outcomes on sound wave material in Table 4.

Tabel 4. T-test Results of N-Gain of Science Literacy

\begin{tabular}{|c|c|c|c|c|c|c|c|c|}
\hline Classes & $\begin{array}{l}\text { Pretest } \\
(x \pm d)\end{array}$ & & $\begin{array}{l}\text { Posttes } \\
(x \pm d)\end{array}$ & & $\begin{array}{l}N \text { gain } \\
(x \pm d)\end{array}$ & & Criteria & $\begin{array}{l}\mathrm{T}- \\
\text { test }\end{array}$ \\
\hline Control & $\begin{array}{l}36.96 \\
13.77\end{array}$ & \pm & $\begin{array}{l}54.88 \\
10.17\end{array}$ & \pm & $\begin{array}{l}0.28 \\
0.07\end{array}$ & \pm & Low & .000 \\
\hline $\begin{array}{l}\text { Experi- } \\
\text { ment }\end{array}$ & $\begin{array}{l}37.92 \\
14.05\end{array}$ & \pm & $\begin{array}{l}64.64 \\
9.50\end{array}$ & \pm & $\begin{array}{l}0.43 \\
0.08\end{array}$ & \pm & Average & .000 \\
\hline
\end{tabular}

Table 4. shows that the control class has an Ngain value $=0.28$ (low criteria), while the experimental class has then an $\mathrm{N}$-gain value of 0.43 (medium criteria). Based on these data in the experimental class there is a significant increase in student science literacy. The result of the T-test analysis, the sig value $(0.00)<$ 
005 which means there is a significant increase in student science literacy. Thus, there is a significant difference in N-gain between the control class and the experimental class. There is an increase in the students' science literacy on each indicator. The detailed data of this increase have seen in Figure 3.

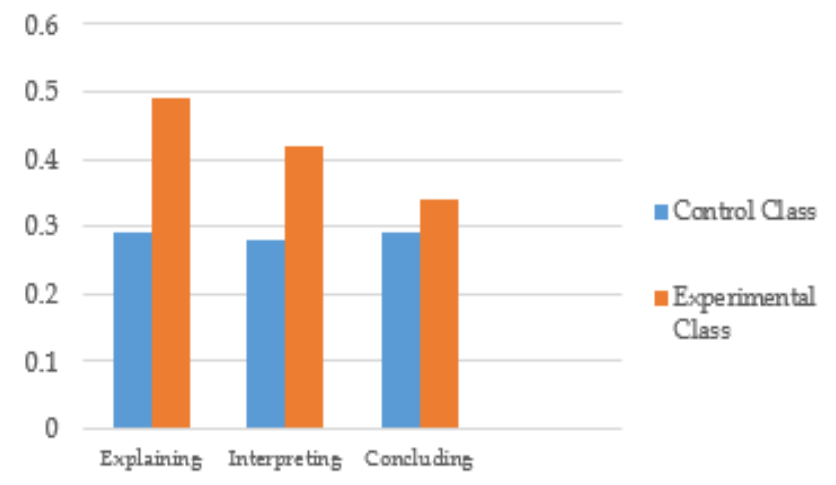

Figure 3. Science Literacy Ability

Based on Figure 3, the science literacy indicator that experienced the highest increase in the experimental class is explaining the scientific phenomenon and interpreting data. The lowest indicator is evaluating conclusions. The conclusion of this research is the STEM-based worksheet could effectively improve the student's science literacy. The indicators show that the science phenomenon has the highest value and the conclusion drawing indicator has the lowest value. In addition, the students have a good or positive response toward the learning using the STEM-based worksheet.

Another study was conducted by Wahyu, et al. (2020). This study was used a quasi-experimental method with a posttest-only control group design. The population of this study was all students at the fourgrade level of the Elementary School Teacher Program of Saint Paul Educational College Ruteng, Indonesia, in the 2018/2019 academic year. The population in the study was 516 students in 9 classes. This research was conducted seven meetings by giving 12 numbers of scientific literacy questions and evaluating 30 scientific items. To determine the feasibility of learning used a science attitude observation sheet with indicators of interest in science, science inquiry, and sensitivity and responsibility in the experimental class and the control class.

The results of the descriptive analysis of students' scientific literacy score of science learning treated through MAR assisted STEM-Based is displayed in Table 5.
Table 5. Recapitulation of Science Literacy Score

\begin{tabular}{lll}
\hline Statistic & $\begin{array}{l}\text { MAR assisted } \\
\text { STEM-Based } \\
\text { learning media }\end{array}$ & $\begin{array}{l}\text { Conventional } \\
\text { Learning }\end{array}$ \\
\hline Amount of Data & $\begin{array}{l}\text { Experiment } \\
87.00\end{array}$ & $\begin{array}{l}\text { Control } \\
88.00\end{array}$ \\
$\begin{array}{l}\text { Amount of Score } \\
\text { Average Score }\end{array}$ & 3969 & 3683 \\
Standard & 76.99 & 58.70 \\
Deviation & 6.27 & 5.31 \\
Average & 39.40 & 29.46 \\
\hline
\end{tabular}

Table 5. shows science literacy score data of students who take science learning with learning using MAR-based STEM-based learning with indicators of scientific literacy questions in the dimensions of scientific contexts, scientific knowledge, and scientific compatibility. The average score of scientific literacy is obtained through three indicators of scientific literacy, namely scientific contexts, scientific knowledge, and scientific competencies producing different scores in the experimental class and the control class. Each dimension of science literacy is displayed in the histogram as shown in Figure 4.

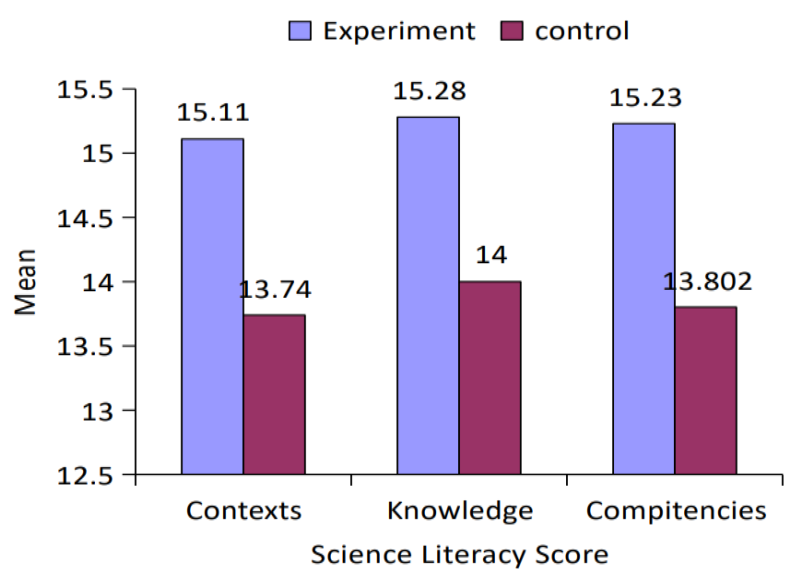

Figure 4. Average Literacy Score of three indicators

The result of this study proves that MARassisted STEM-Based in science learning has a positive impact on students' science literacy. There is a positive impact of MAR-assisted STEM-Based on students' science literacy. Learning through MAR-assisted STEM Based is a learning process insisting students be actively finding concepts through exploration activity using MAR media. The results of this study recommend that the alternative approach of learning in science learning in science learning can be implemented through MAR-based STEM-based learning. Before carrying out learning first, there is a tutorial on the development of mobile augmented reality applications on the material taught according to the time of learning. Teachers and lecturers, especially for STEM- 
oriented education, should pay attention to four main things, namely, learning material and resources, learning activities or activities, learning models and approaches that are collaborated with STEM, and the implementation of evaluation through authentic assessment.

\section{Conclusion}

Based on the literature study, it can be concluded that the use of STEM-based learning effectively improves the student's science literacy. The results of the research analysis showed that the results of the pretest scores of students had low concept understanding in the experimental class and the control class. After being given treatment, the results of the post-test scores showed a significant increase in the experimental class.

\section{Acknowledgments}

Many thanks to the leadership of STKIP Weetebula who has given me the opportunity to continue my studies and provided support in writing this article. Also, to the promoter lecturers and co-promoters who have provided guidance and to all family members who have supported me.

\section{References}

Asmuniv. (2015). Pendekatan Terpadu Pendidikan STEM Upaya Mempersiapkan Sumber Daya Manusia Indonesia Yang Memiliki Pengetahuan Interdisipliner Dalam Menyosong Kebutuhan Bidang Karir Pekerjaan Masyarakat Ekonomi ASEAN (MEA). Retrieved from: http://www.vedcmalang.com/pppptkboemlg/i ndex.php/menuutama/listrikelect ro/1507- asv9 [Indonesian]

Brown, R., Brown J, Reardon K \& Merrill C. (2011). Understanding STEM: Current Perceptions. The Technology and Engineering Teacher, 70(6), 5-9. Retrieved https://eric.ed.gov/?id=EJ918930

ByBee, R.W. (2010). Advancing STEM education: A 2020 vision. The Technology and Engineering Teacher, 70(1), 30-35. Retrieved from: https://eric.ed.gov/?id=EJ898909

Capraro, R., Capraro, M., \& Morgan, J. (2013). STEM Project-Based Learning: An Integrated Science, Technology, Engineering, and Mathematics (STEM) Approach. https://doi.org/10.1007/978-94-6209$\underline{143-6}$
Depdiknas. (2003). Undang-undang RI No. 20 tahun 2003 tentang sistem pendidikan nasional. Jakarta. [Indonesian]

Firman, H. (2007). Laporan Analisis Literasi Sains Berdasarkan Hasil PISA Nasional Tahun 2006. Jakarta: Pusat Penilaian Pendidikan Balitbang Depdiknas [Indonesian]

Fraenkel, J.R, Wallen, N.E., Hyun, H.H. (2011). How to Design and Evaluate research in Education Boston: Pearson. McGraw-Hill Higher Education

Guthrie, J., Wigfield, A., \& VonSecker, C. (2000). Effects of integrated instruction on motivation and strategy use in reading. Journal of Educational Psychology, 92, 331-341. https://doi.org/10.1037/0022-0663.92.2.331.

Kartini, F. S., Widodo, A., \& Winarno, N. (2021). STEM project-based learning on student's STEM literacy: the case of teaching earth layer and disaster. Journal of Physics: Conference Series, 1806(1), 12221. https://doi.org/10.1088/17426596/1806/1/012221

Khaeroningtyas, N., Permanasari, A., \& Hamidah, I. (2016). STEM Learning In Material Of Temperature And Its Change To Improve Scientific Literacy of Junior High School. Jurnal Pendidikan IPA Indonesia, 5(1), 94-100. https://doi.org/10.15294/jpii.v5i1.5797

Lou, S. J., Chou, Y. C., Shih, R. C., \& Chung, C. C. (2017). A study of creativity in CaC 2 steamshipderived STEM project-based learning. Eurasia Journal of Mathematics, Science and Technology Education, 13(6), 2387-2404. https://doi.org/10.12973/EURASIA.2017.01231 A

Lu, H.K., \& Lin, P.C. (2018). A Study on the Effect of Cognitive Style in the Field of STEM on Collaborative Learning Outcome. International Journal of Information and Education Technology, 8(3), 194-198. https://doi.org/10.18178/ijiet.2018.8.3.1032

Minister of Education and Culture Regulation. (2015). Minister of Education and Culture Regulation Number 23 of 2015 concerning the Growth of Character. Jakarta.

OECD. (2013). PISA 2012: Assessment and Analytical Framework: Mathematics, Reading, Science, Problem Solving and Financial Literacy. In Autistic States in Children. https://doi.org/10.4324/9781003090366

Oktavia, R. (2015). Penerapan Model Pembelajaran Model Proyek dengan Pendekatan Integrasi STEM dalam Meningkatkan Penguasaan Konsep dan Keterampilan Berpikir Kreatif Siswa SMP pada Materi Gelombang Bunyi. Thesis. Bandung: Universitas Pendidikan Indonesia. Retrieved 
from: $\quad$ http://repository.upi.edu/27825/

[Indonesian]

Persaud-Sharma, D. (2012). Pedagogical methods to promote STEM literacy. International Journal of Science, Mathematics and Technology Learning, 19(4), 1-12. https://doi.org/10.18848/23277971/cgp/v19i04/49014

Sarwono, J. (2006). Metode Penelitian Kuantitatif dan Kualitatif. Yogyakarta: Graha Ilmu. [Indonesian]

Stohlmann, M., Moore, T., \& Roehrig, G. (2012). Considerations for Teaching Integrated STEM Education [Consideraciones para enseñar educación STEM integrada]. Journal of Pre-College Engineering Education Research, 2(1), 28-34

Sulistiyowati, S., Abdurrahman, A., Jalmo, T. (2018). The Effect of STEM-Based Worksheet on Students' Science Literacy. Tadris: Jurnal Keguruan dan Ilmu Tarbiyah. 3(1). 89-96. https://doi.org/10.24042/tadris.v3i1.2141

Tseng, K.-H., Chang, C.-C., Lou, S.-J., \& Chen, W.-P. (2013). Attitudes towards science, technology, engineering and mathematics (STEM) in a project-based learning (PjBL) environment. International Journal of Technology and Design Education, 23(1), 87-102. https://doi.org/10.1007/s10798-011-9160-x

Wahyu, Y., Suastra, I., Sadia, I., \& Suarni, N. (2020). The Effectiveness of Mobile Augmented Reality Assisted STEM-Based Learning on Scientific Literacy and Students' Achievement. International Journal of Instruction, 13, 343-356. https://doi.org/10.29333/iji.2020.13324a

Zollman, A. (2012). Learning for STEM Literacy: STEM Literacy for Learning. School Science and Mathematics, 112(1), 12-19. https://doi.org/https://doi.org/10.1111/j.19498594.2012.00101.x 